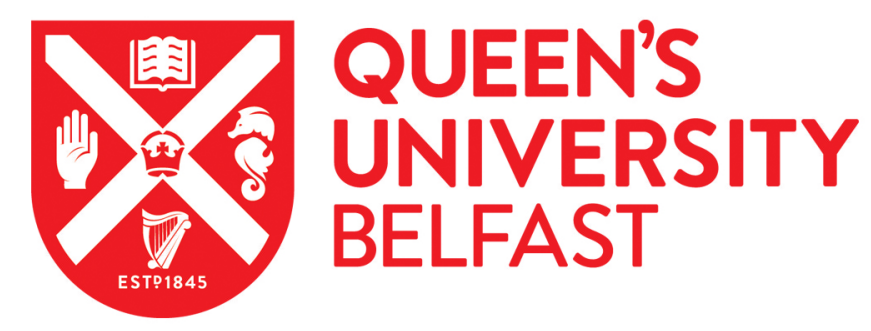

\title{
The executive committee of the Greek Professional Association of Social Work in an age of austerity: examining its response
}

Pentaraki, M. (2015). The executive committee of the Greek Professional Association of Social Work in an age of austerity: examining its response. European Journal of Social Work, 18(1), 140-155.

https://doi.org/10.1080/13691457.2013.844683

Published in:

European Journal of Social Work

Document Version:

Peer reviewed version

Queen's University Belfast - Research Portal:

Link to publication record in Queen's University Belfast Research Portal

Publisher rights

() 2013 Taylor \& Francis

The Version of

Record of this manuscript has been published and is available in

European Journal of Social Work $2015 \mathrm{http}: / / w w w . t a n d f o n l i n e . c o m / 10.1080 / 13691457.2013 .844683$

\section{General rights}

Copyright for the publications made accessible via the Queen's University Belfast Research Portal is retained by the author(s) and / or other copyright owners and it is a condition of accessing these publications that users recognise and abide by the legal requirements associated with these rights.

Take down policy

The Research Portal is Queen's institutional repository that provides access to Queen's research output. Every effort has been made to ensure that content in the Research Portal does not infringe any person's rights, or applicable UK laws. If you discover content in the Research Portal that you believe breaches copyright or violates any law, please contact openaccess@qub.ac.uk. 
Pentaraki, M. (2015). The executive committee of the Greek Professional Association of Social Work in an age of austerity: examining its response. European Journal Of Social Work, 18(1), 140. doi:10.1080/13691457.2013.844683

\section{Abstract}

This paper explores the response by the Greek Association of Social Workers (SKLE) to Greece's current economic crisis. Socioeconomic conditions in Greece have deteriorated rapidly since the imposition of a Structural Adjustment Programme as a condition of the loan Troika provided to Greece to address its class-based public debt crisis. Interviews were conducted with SKLE Executive Committee members to examine SKLE's response in the context of newly raised inequalities.

Research results show that SKLE recognised the negative consequences to both service users and its members. However, SKLE continues to reformulate its strategy mostly as a social partner. SKLE's previous strategy entailed amongst other things the analysis of policy proposals and participation in welfare related government committees. This strategy is no longer relevant because decisionmaking powers have been transferred to transnational bodies. This paper elaborates on these findings and discusses the barriers that prohibit SKLE from differentiation of its strategy. Although the research is country specific, it has implications for the broader global debate because professional associations must reformulate their strategies for better serving of both their constituents and the collective good based on the social justice mandate of the profession.

\section{Abstract (Modern Greek):}

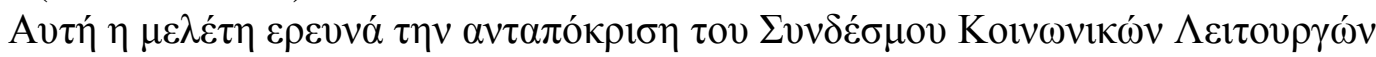

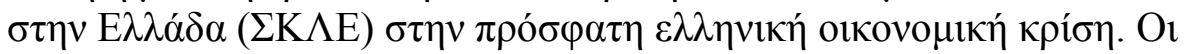

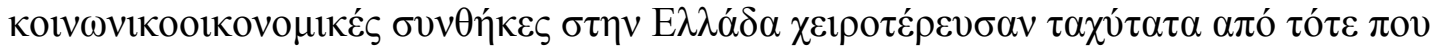

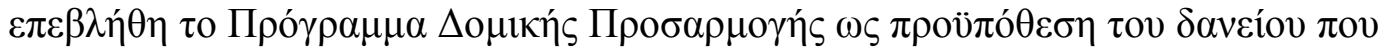

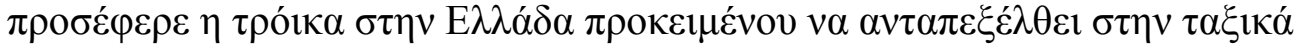

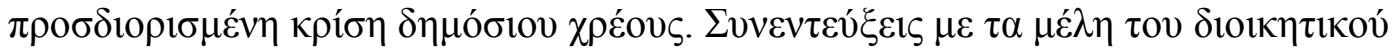

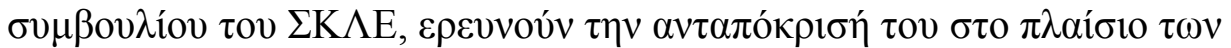

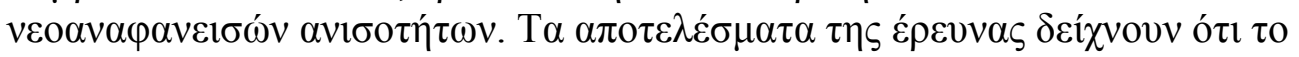

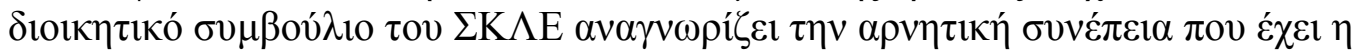

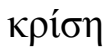

\section{Keywords}

- organisations,

- professions,

- social policy,

- professional association of social work,

- austerity,

- Greece,

- structural adjustment programme,

- addressing inequalities, 


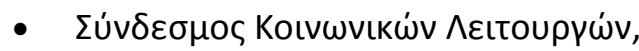

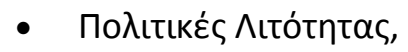

- $E \lambda \lambda \alpha \dot{\alpha} \delta \alpha$,

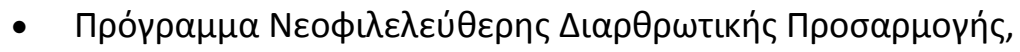

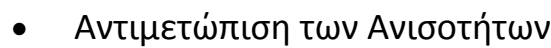

\section{Introduction and context}

In 2001, professional associations of social work (PASW) around the world adopted an international definition of social work entailing a commitment to social change and social justice. This is evident in the code of ethics that the professional associations have developed to reflect that commitment. Under the current socioeconomic conditions of rising inequalities (United Nations [UN], 2011), the aim of social justice is made more difficult as the achievements of past social struggles are undermined and in many cases reversed. The changing socioeconomic conditions raise important questions about how professional associations respond to the challenge. The present paper aims to address this question by examining how the leadership of the Greek PASW has responded to the deteriorating socioeconomic conditions. This may have international significance because the responses could determine the direction of the social work profession. Before the research is presented, the paper starts with a short presentation on the context of the inequalities, as well as a review of the available English-language literature addressing PASW activity in liberal and non-liberal democracies.

Many countries across the globe have experienced a deterioration of social-economic conditions (UN, 2011) because of global neoliberal restructuring (Harvey, 2005). Inequalities have increased rapidly. According to Milanovic (2010), an economist with the World Bank, the incomes of the world's top $1.75 \%$ earners now exceed those of the bottom $77 \%$. A number of research studies (among others, see Wilkinson \& Picket, 2009) have documented the fact that unequal societies have more social problems than more equal societies. Thus, inequality clearly undermines the fulfilment of human capabilities.

Social spending cuts and the deterioration of socioeconomic conditions are evident in both Europe (European Commission, 2012) and the rest of the world (IMF, 2012). One country that is experiencing the most drastic deterioration in its socioeconomic conditions is Greece, where $68 \%$ of the population is living below the 'at-risk-of-poverty' rate (i.e. having an income below $60 \%$ of the national median) (European Commission, 2012, p. 46), and where the unemployment rate is $25 \%$ (Eurostat Press Office, 2012); for women, the unemployment rate reaches $31 \%$ and for young women it is $65 \%$. Additionally, there was an increase in the suicide rate by $22 \%$ from 2009 to 2011 , an increase of HIV infections by $52 \%$ since 2010 because of the abolition of street prevention programmes, an increase of homelessness rate by $20-25 \%$ compared with the pre-crisis rate (Fondeville \& Ward, 2011; Greek National Medical Conference, 2012; Kentikelenis et al., 2011). These deteriorating conditions in Greece are the result of a Structural Adjustment Programme (SAP) imposed in 2010 by the so-called Troika-the European Union (EU), the European Central Bank (ECB), and the International Monetary Fund (IMF) - as a condition of the loans provided to Greece to deal with its high public debt. Troika imposed a SAP on Greece as a condition of the loans it provided to Greece. The most notable characteristic of this SAP is the imposition of drastic social spending cuts despite the fact that Greece ranked third from the bottom of the hierarchy of the EU15 countries in social spending on benefits-in-kind per head in purchasing power standards (PPS) ${ }^{1}$ (Petmesidou, 2006). 
The debt crisis was caused not by social spending, as has been widely assumed in order to legitimise the social spending cuts (Pentaraki, 2013a). Rather, the crisis was caused by, among other things, bank bailouts, a low corporate taxation rate and high military spending (Pentaraki, 2013a).

The increase of social problems and the decrease of social spending create new challenges for the social work profession. A body of academic social work research has made normative claims that, because of the social work profession's emphasis on social change and social justice, the profession should actively engage in the struggle for social justice (Lavalette \& Ferguson, 2007; Ferguson \& Woodward, 2009; Pentaraki, 2013a) and the remediation of socioeconomic inequalities. However, a section of the critical academic literature presents pessimistic accounts of the social work profession's present direction. For example, two books, The Road Not Taken (Reisch \& Andrews, 2002) and Unfaithful Angels (Specht \& Courtney, 1994), employ titles that encapsulate the belief that the profession has abandoned its historical mission for social change, despite the fact that the majority of mission statements by PASWs advocate social change and social justice. This study fits within this body of literature and is important, because it aims to explore the direction of the PASWs by examining the Greek PASW. Up to now, most research conducted on PASWs in liberal democracies relates to bibliographical or historical information (Payne, 2002), and normative and/or descriptive accounts (Arad, 1972; Gillingham, 2007). There is little empirical research conducted on the strategies employed currently or past by PASWs; Mendes (2003) is one exception. He explored the social action history of the Victorian state branch of the Australian Association of Social Workers through a content analysis of its archives and documented that the profession failed to fulfil its commitment to promoting more equitable social policy outcomes. Among the contributing factors he discussed are deficits in skills, resources and education. The inability of PASWs to fulfil their value-based commitment to social justice has been also documented by $\mathrm{Yu}(2006,2008)$, Mazibuko and Gray (2004) and loakimidis (2011) who explored PASWs' past performance in non-liberal democracies, such as martial law and apartheid. Yu $(2006,2008)$, for example, explored the record of the Philippine PASW under martial rule through a content analysis of the association's journal. He found that the representatives of the profession not only accommodated and failed to challenge the regime, but also legitimised it. He suggests three factors for this stance; firstly, the need to protect its space and the legitimacy of the discipline; secondly, the 'interrelationship between the leadership of the professional association and the Marcos regime'; and thirdly, the 'congruence between the ideological orientation of some members of the professional association and the new order under Marcos' (Yu, 2008, p. 5). Similarly, through a content analysis of the Greek professional archives, loakimidis (2011) found that during the US-sponsored junta of 1967-1974, formal social work was obedient to the regime in exchange for demands of professional recognition. Likewise, in South Africa during the apartheid, Mazibuko and Gray (2004, p. 131) report that 'fragmented, raciallybased and regional social work formations emerged in line with or as a reaction to apartheid doctrine and policies'.

From this scholarly work, it is evident that under difficult conditions, the leadership of the profession has been mostly accommodating rather than actively engaging in struggles to transform oppressive conditions, with the notable exception of some segments of the profession in Latin America (Reisch \& Jani, 2012).

The aforementioned literature raises important concerns in terms of how the leadership has responded to difficult circumstances both in liberal and in non-liberal democracies. This paper 
intends to explore that issue of concern further by examining how the leadership of the Greek PASW has responded to the present difficult circumstances of austerity and whether its response provides any lessons.

Having discussed the relevant literature, I now describe the research methodology employed to explore Greek Association of Social Workers (SKLE) executive committee's response to this current age of austerity. Afterwards, based on my findings, I present a discussion of the potential factors that may prohibit the development of a new response that can challenge inequalities. Lastly, I conclude by discussing the implications of this research to PASWs and to the social work profession as a whole.

\section{Study method}

A qualitative study was conducted to explore the strategy that SKLE has used and continues to use in the context of the SAP, as well as SKLE's understanding of the consequences of the SAP. This research is informed by a critical social theory, in which engagement in research is informed by aims to contribute to changing practices and hoping to advance claims of social justice (Kincheloe \& McLaren, 2000).

\section{Data collection}

Data were collected during two semi-structured focus groups and three individual in-depth, one-onone interviews. Members interviewed individually were those who could not participate in the group interview (i.e. one member), or those who had differentiated themselves during the group interviews as individuals who might offer interesting insights. When I approached the SKLE President, she suggested that group meetings were preferable because of members' limited availability. This suggestion also met methodological research requirements because SKLE's executive meets as a collective body.

Data collection by interview involved semi-structured questions. The questions that guided this component of the overall research included the following main questions:

What strategies and interventions have you used prior to and during the crisis?

In what ways has your response changed?

The interviewer gave interviewees the opportunity to address areas they found important and to elaborate on any other areas they found relevant.

\section{Participants}

SKLE was established in 1955. It is the main representative body for the social work profession in Greece. From 1981 through 2010, SKLE has been successful, to varying degrees, in influencing policy outcomes. SKLE provides professional and scientific representation for 5500 social workers in Greece. Over the past few years, it has changed its constitution so that it also functions as a trade union. It has branches in most major Greek cities, but the General Executive Committee, elected every two years, performs most of its work in Athens. 
Participants in the study consisted of members of SKLE's Executive Committee. These individuals possessed a wide range of experience in SKLE and in their professional fields. Individuals' SKLE experience as elected committee members ranged from two to twenty years. Their professional experience ranged from less than one year to twenty-six years. The majority had worked from ten to fifteen years. Some individuals had worked in local government; others had worked in central government. The majority were permanent public sector employees, but the two youngest members worked under limited contracts.

The researcher contacted the SKLE president to discuss the research project and to secure approval to inform the remaining committee members of the research and ask for their permission. Ethics approval for the interviews was obtained through the Ethics Committee of Liverpool Hope University. A semi-structured interview guide was developed. ${ }^{2}$ The interviews were conducted at SKLE's offices between December 2011 and September 2012.

\section{Ethical considerations}

Informed consent was sought and given by all participants, who signed a relevant form. It was clearly explained that the interviews would be part of research that was going to be published. The participants clearly understood that the research was going to be published with their names withheld. However, because of the small number of participants, some readers may have been able to infer particular participants' identities. Consequently, the author took care to protect respondents from such inferences, and in places, where this could not be done data were excluded from the analysis. The data, thus excluded, however, did not affect the themes that arose from the interviews or the discussion and conclusions of the present paper.

\section{Data analysis}

The interviews for this component of the research were thematically examined to identify, analyse and report patterns (i.e. themes) within the data (Braun \& Clarke, 2006). Transcripts of the interviews were carefully reviewed for summarisation by assignment of different words/phrases (i.e. codes). These codes were then analysed, reviewed, and merged to form themes. This process entailed the following phases: (1) transcription and familiarisation with data; (2) generation of initial codes; (3) search for themes; (4) review of themes; and (5) definition and name of themes.

The 87-minute focus group and the 37-minute focus group were recorded and transcribed, as were the three individual interviews.

\section{Findings}

From our results, we can identify a number of overarching themes. These include (a) the doors are closed now, a theme that refers to a lack of access to decision-making processes; (b) there is war in the job market, a theme that refers to the increase in competition for employment that has increased interviewees' workloads and changed their approaches to case interventions; (c) now we have to formulate demands for both the service users and ourselves; and (d) we are all to blame. I discuss these themes in more detail below. 


\section{Theme (a): Participants' perceptions of their ability to influence policy developments: 'The doors are closed now'}

In their discussions of SKLE's ability to influence policy developments, participants acknowledged that, in the past, they were able to influence policy developments. At present, they cannot. They stated that their ability to influence policy developments was based on a number of factors, such as good personal relationships with relevant political actors and participation in relevant task forces and committees. These practices resonate with practices of clientelism and social partnership, respectively. They noted that their ability to influence policy matters started to weaken, albeit slowly, in 2005. When participants were asked if they previously had an open method of communication, they stated that they had. One noted that it was based

... on the respect and acceptance at the institutional level for our stance. We used to go [to the state] with our [scientifically] based demands. These demands were not sectoral or personal; they were demands for the citizens. We passed exams for 55 years; we have survived. This is no longer the case.

When the participants discussed their reasons why the doors are closed now, they mentioned a number of factors. The following transcript excerpt highlights the factors:

The doors are not as open now because there are more demands from many other sectors ... the needs are greater because the state does not pay attention to the welfare state we serve due to [...] important economic problems the country faces. We have noted since 2005 that the doors have started to close. It is harder for the association to make demands on institutional issues. It was easier to make these demands in the past.

The participants realise that traditional networks of personal contacts and lobbying tactics previously established and used with cabinet ministers and government officials may not give them the influence they desire. They stated:

... the ministry we belong to knows ... and tries to respond to our demands ... - But, despite that, the central government does not give in. Even if the minister or general secretariat with whom we collaborate [...] might advocate on our behalf for that issue $\mathrm{e}^{3}$ so we can be excluded from that policy and move upwards at the finance ministry [...] everything is stopped.

Participants' comments reflected their awareness that the democratic deficit that resulted from the imposition of the SAP had rendered their strategy obsolete. Their comments also reflect their awareness that no amount of social research, evidence-based policy reports, memoranda, or traditional lobbying tactics could change the imposed neoliberal policy agenda. However, this awareness had not sufficiently mobilised them to change their strategy. From the beginning of the first phase of implementation of the SAP through to the time the interviews were conducted, SKLE executive members declared that they had continually commented on policies and socioeconomic conditions. Their criticism was however, barely heard. Their recommendations that the government discontinue certain detrimental policies were ignored. The participants stated that they had organised conferences on themes relevant to the crisis. They had also issued press releases to invite their members to participate in strikes. Despite these actions, no major changes had been made to their strategy. 
We must ask why SKLE remains in this frozen state. Has its previous identity as a social partner immobilised it? Has it been co-opted by the consensual politics that transpired during its previous engagements as a social partner? Is it possible that SKLE and the majority of Greek citizens are in a state of shock caused by rapid restructuring?

This limited progress made in changing strategy must be examined within the context of the participants' previous successes. SKLE traditionally derived its power from both a social dialogue strategy and clientelist relationships with the political parties in power. This has perpetuated its problems with the establishment of alternative strategies. If we employ the suggestion offered by Nancy (1992, cited in Swyngedouw, 2011) that politics can be reduced to a situation of institutionalised social management in which all problems are addressed by administrativeorganisational technical means, the ability to question issues and policies disappears. The SAP imposed policies that undermined and annulled the role of social partners, such as unions and professional associations. There is thus, an urgent need for participants to retain their credibility so they can reformulate their role.

Scholars have identified four different uses for the concept of social dialogue (Hyman, 2010). First, social dialogue can be used as another term to describe industrial relations. Second, it can be regarded as a process, whereby information and viewpoints can be exchanged. Third, it can be seen as an institutional arrangement intended to promote consensus. Fourth, it can be seen as a strategy for social partnership and the avoidance of conflict.

SKLE's traditional strategy appears to be situated between two of these uses, but must also be explained with regard to clientelistic practices. SKLE has been involved in the exchange of information and viewpoints and in institutional arrangements, such as committees and task forces that were developed with the intention of avoiding conflict. The process of conflict avoidance has been intensified by interactions with party-affiliated personal contacts. ${ }^{4}$ It can be argued that these personal/political contacts embodied clientelistic practices, because they involved 'asymmetric but mutually beneficial relationships of power and exchange' (Roniger, 2004, p. 353). ${ }^{5}$ These relationships have intensified the participants' acceptance of a social partnership strategy and have intensified their view of themselves as social partners, because they were once able to influence policy developments.

\section{Theme (b): 'Now we have to formulate demands for both the service users and ourselves'. In what way do we differ from the service users?}

In this research, another important theme emerged. Participants realised that SKLE needed to formulate demands for both service users and social workers. This theme may have developed because participants realised that the negative effects of the market-driven agenda had resulted in the imposition of the SAP on both service users and practitioners. It may also have developed because participants realised that the transfer of responsibilities to the private sector resulted in time-limited funding with expiration dates for social services. One participant stated

... the state has abandoned its role ... thus, welfare programs have specific expiration dates for both service users and social workers. And currently we experience many problems with colleagues who work in these agencies. For example, the Greek Red Cross has a big problem with payment. 
Tomorrow, colleagues will begin to strike for several hours. However, in other agencies, colleagues get paid every three or four months, or, at most, every two months. ... Often, we have been tempted to say 'in what way do we differ from the service user?' The person [service user] is in crisis because $s /$ he ... does not have the resources to meet basic needs. But if we do not receive our pay, how do we differ from him/her? Essentially, we face the same problems [as the service users] and our needs are ever-increasing needs.

Participants' realisation that the needs/demands of service users and the social work profession are of the same type, led them to change SKLE from a scientific association into a union that works towards scientific and labour union goals.

\section{Theme (c): Increasing antagonism in the job market: 'There is a war in the job market'}

Another theme that emerged was participants' perception that there is a war in the job market. This theme is based on participants' awareness of the limited job market. Some noted that professionals from other fields (e.g. social religious studies) have applied for their jobs. Thus, SKLE has devoted a significant amount of time to the protection of the professional rights of the social work profession and the defence of their members. Challenges to the professional identity of social workers have increased as employment opportunities have declined. SKLE has increasingly engaged in the definition and protection of the boundaries of the profession and the establishment of social workers' professional identities. SKLE has engaged in a process similar to the engagement of other PASWs (Mazibuko \& Gray, 2004). Unfortunately, these issues will, in all likelihood intensify, as social work becomes deregulated. One participant stated,

We have social work colleagues in precarious positions. These needs must be met by the union. You cannot allow social workers that are in general, employed under a [precarious] contract to work four hours a day and not offer them union protection.

\section{Theme (d): 'We are all to blame}

Participants discussed an interesting theme related to collective responsibility. One member stated

As good citizens, haven't you gotten a traffic ticket and tried to find ways to avoid paying it? When you go to the tax office, if you know someone there, don't you negotiate with him/her? Aren't you a good citizen when you go to the hospital? If you know someone from personnel, don't you try to get a better place on the waiting list? ... It is very important what he [Pagkalos, the deputy prime minister] said: 'We ate them all together'.

This statement clearly endorses the dominant explanation provided by establishment politicians and the mass media, which claims that all people in Greece are responsible for this crisis. This attempt to blame all people collectively is both problematic and unethical. It ignores the fact that the class nature of successive government policies led to the public debt crisis (PDC), and clearly reflects an attempt to relocate the blame from systemic reasons to individual reasons (Pentaraki, 2013a), a view that did not remain unchallenged by other members of the Executive Committee. The theme of collective responsibility was clearly a contested one. This attempt, combined with the inability of the majority of the participants to connect the events in Greece to events occurring elsewhere, despite 
direct questions from the interviewer, might explain the profession's inability to change its response. Characteristically, to a question from the author about whether, during the economic crisis, there was also a need for intervention outside of Greece, one participant stated

If you do not fight for your home you do not fight for anything [...]. It is my personal position that the problem with the economic crisis is here and it is here that we need to put all our weight.

After the author's further questioning/probing about whether the consequences experienced as a result of the economic crisis are shared by other countries, another member conceded that

Generally speaking there have been cuts in England and in education specifically and an uprising happened from what I know. This is though something we have not examined.

The discussion then continued with a member stating that 'if we have not seen that, where is the international association to remind us of that connection [...]'.

Participants' comments reflect an inability to connect the issues that Greece faces with similar issues elsewhere, which might reinforce the belief that the issues in Greece are related to factors specific to Greece.

\section{Discussion}

All four themes extracted from the interviews provide insights into SKLE's strategy for the rectification of inequalities. During the interviews, SKLE's policies and actions were reviewed. These included the issuance of policy statements that criticised policies, conversations with relevant cabinet ministers, the organisation of conferences to explore new themes, etc. All these actions have proven futile: 'The doors are closed now'. In the present political-economic context, SKLE's ability to influence policies by traditional means has deteriorated. Changing socioeconomic conditions have destroyed their role as social partner. Scholars have argued that one of the main aspects of the European Social Model is the key role of social partners in socioeconomic management (Jepsen \& Serrano, 2005). The destruction of the role of social partners in socioeconomic management signals the destruction in practice of the European Social Model. It also signals the transfer of decisionmaking powers from the national level to the transnational level. When decision making was performed at the national level, it facilitated the development of clientelistic relationships based on party membership. Traditionally, certain members of the SKLE Executive Committee maintained relationships with relevant ministers based on party politics that facilitated an open-door policy. This policy, combined with the social democratic phase of capitalism (i.e. a post-dictatorship social contract in Greece), led to certain members' abilities to influence policy developments. Now that the social democratic phase of capitalism is over and relevant actors can no longer make compromises, this is no longer the case.

Despite these changes in social-economic conditions and decision-making powers, SKLE has not made significant changes to its strategy. The research findings suggest several factors that might explain this failure to make changes. Organisational demands placed on SKLE by the deteriorating conditions of their membership may have forced Executive Committee members to spend considerable time focused on a case-study approach rather than a structural approach designed to address socioeconomic conditions. Payne (2002) reached similar conclusions about the role of the British Association of Social Workers with respect to community activism and trade unionism. Payne believes these issues continue to exist. SKLE's failure to adopt a structural approach appears to be 
combined with an additional organisational factor. All members of the Executive Committee have other professional paid work and their involvement in SKLE is voluntary which leaves little time for committee work. This finding echoes Mendes (2003) discussion about the absence of resources as a contributing factor. In addition, there is a membership factor. Members of the Executive Committee stated that SKLE is only as strong as its members. They noted that members must also initiate actions. In Greece, social workers work in deteriorating conditions. This leaves little room for activism.

Karger and Hernandez (2004) expressed a similar opinion in their discussion of the decline of the public intellectual in social work. This decline in activism by members, coupled with the collective blaming engaged in by some members during discussions of the causes of the PDC, may explain why SKLE has not actively formulated a strategy to address the broader political picture. The theme of collective blaming reflects the legitimisation of the dominant discourse of the governing party, which in turn raises concerns about the possible ideological alignment of part of SKLEs leadership with the governing regime. This suggestion seems to be similar to the one offered by Yu $(2006,2008)$, Mazibuko \& Gray (2004) and loakimidis (2011) as to the ideological alignment of the PASWs with the governing regime as a factor that explains their inability to engage in struggles of resistance to oppressive regimes. An additional factor that might explain that inability relates to current pressures and organisational limitations that have resulted in SKLE's casework orientation. A casework approach limits the time available to formulate a strategy to address the broader political picture. Specht and Courtney (1994, p. 60) argued that this inability to formulate a strategy might have occurred ' $[. .$.$] because the profession itself is unclear about its social mission and uncertain about$ the practice methodology that is best suited to carry out one or another mission'. Social work has always been a contested profession, with different conceptualisations about what it is and what can/should be. This is evident in the history of the leadership of the social work profession in South Africa, Philippines and Greece, as discussed earlier. This literature in relation to the present findings highlights the need of a debate within the social work profession.

There is clearly a need for a 'debate' within social work about where it is going. Let us hope that social work becomes a profession that speaks truth to power and challenges oppression and inequality in renewed ways. Identification of the barriers to the formulation of a new strategy may open new lines of inquiry to help strengthen SKLE's prospects for renewal.

\section{Limitations and future research}

The transfer of these findings to other social work professional associations should be attempted with caution and care. The history of the social work profession in Greece differs from that of social work professional associations in other nations. However, because many European countries have been facing social spending cuts and rising inequalities, these findings are relevant. This paper hoped to examine SKLE executive committee's response to austerity measures in Greece, but we should remember that austerity measures are being imposed across the globe. Greece provides a useful example because the deterioration of its economic conditions is extensive. A thorough understanding of the implications of this crisis is important. It can provide the context for a careful examination of the profession's response to the economic crisis.

Future research should apply different methodological approaches, such as individual interviews, to ascertain whether members will provide different responses. It would also be interesting to attempt new research to ascertain whether changes in political context affect members' understanding. In 
addition, a triangulation method could be applied to content analysis of SKLE's written material and it would be interesting to explore the perceptions of SKLE's membership (rank and file) rather than focusing on the leadership of the profession. One limitation to the research was determined by the simple lack of time that SKLE committee members could make available for interview. Future research should look for ways around that limitation.

\section{Implications and conclusion}

This research entailed a qualitative study of interview responses by members of the Executive Committee of the Greek Professional Association of Social Workers about the Association's strategy in the context of rising inequalities. Although the research is country-specific, it has implications for the broader European and global debate, because the deterioration of socioeconomic conditions and increased pressures faced by the welfare state continue to occur at both EU and global levels. Across the EU, austerity and social spending cuts have been imposed through new EU economic governance guidelines, which impose fiscal constraints on budget spending (Pentaraki, 2013). The deterioration of EU and global socioeconomic conditions make the findings of the present study relevant beyond the national context of Greece. Overall, the messages emerging from the present findings can inform (1) the leadership, as well as rank and file of SKLE and associated professional groups throughout Europe and beyond; and (2) social work academics and social work education.

\section{Messages for the leadership of SKLE and other PASWs, as well as rank-and- file}

The social democratic phase of capitalism has ended in Western countries. Capitalist forces are able to impose a market-driven agenda with no restrictions. No need exists for class compromise and related tools, such as a social partnership strategy. The results of this study demonstrate that, despite dramatic changes in socioeconomic conditions, the leadership of SKLE continues to employ a strategy rooted in the past. This case study of SKLE provides some insights into PASWs leadership. These associations continue to operate as they have in the past because of a number of factors. First, PASWs operate within a social partnership culture. This culture does not correspond to the current, prevailing neoliberal phase of capitalism. PASWs must reconsider their traditional strategies if they hope to remain relevant to their members' needs. Additional barriers include party identities, membership and organisational factors, and the hegemonic success of the imposition of collective guilt. These factors undermine a commonly held assumption that the social work profession is mobilised by social justice ideals. These factors serve as barriers for the profession's achievement of a strong activist orientation. 'An activist professional orientation would have been essential to achieve the substantive professional goals of social justice and economic redistribution' (McDonald, Harris, \& Wintersteen, 2003, p. 201), confirming a theoretical conclusion reached by Marston and McDonald (2012) about the need to reconceptualise the political agency of the social work profession. The profession employs social justice rhetoric and denounces social spending cuts, but this rhetoric is not translated into activism.

For the leadership of SKLE to continue to base its actions on strategies appropriate to past socioeconomic conditions is disastrous, yet although SKLE leadership recognises that the doors are closed, it continues to apply the same outdated practices. At the moment, research examining the behaviour of other PASWs in the global arena is not available. However, repetitions of this behaviour in the global arena by other associations can be inferred by examining the programmes of the 
international and European conferences of Social Work Professional Associations organised since the beginning of the financial crisis. It seems that the PASWs have attempted to address the consequences of the financial crisis by the inclusion of relevant keynote addresses and/or workshop themes (for example, see IASSW \& ICSW \& IFSW, 2010, 2012). These themes clearly have a social justice rhetoric, but they have not yet been translated into a coherent activist strategy. It is apparent that engagement in the respectable world of conference organisation and academic authorship is insufficient in itself. To paraphrase slightly Marx's Eleventh Thesis on Feuerbach: We have already interpreted the world in various ways; the point is to change it. Furthermore, not only have predominantly western ${ }^{6}$ PASWs failed to actively engage in changing the world, but also the international network of PASWs, that is, the IASSW, has played a defensive role, concentrating efforts on securing a minimum social protection safety net for the poorest, such as that advocated by UNICEF (Donald, 2011). This focus not only does not challenge existing rates of inequality but also implies, in a way, that a certain level of inequality is acceptable and that the role of these organisations is to lessen the pain for the most economically vulnerable sections of the world. It is necessary to move away from that response, because it can be interpreted as accepting the inevitability of the neoliberal restructuring and its casualties. It appears to be concerned only with managing the problems incurred by neoliberal restructuring rather than challenging it.

Thus, the findings of this research have relevance to all PASWs, both their leaderships and rank and file. The messages have relevance too for social work education and social work academics in terms of the changes they need to apply, so that they can be more relevant to people's lives and the social justice values of the social work profession.

However, it is not enough to just criticise the role of the PASW's leadership; it is equally important to look at the role of the rank-and-file membership. A number of questions immediately arise: Have the rank and file ceded responsibility for organisation to its leadership? Do members attend the national membership conferences? Do they agree with the leadership? If the leadership is immobilised, it is up to the rank and file to take action. This may not have happened in the past because rank and file had jobs and trusted the leadership, but changing times necessitate changing duties, to paraphrase a trade union phrase. Rank-and-file are thus faced with a number of options: They can demand a change in leadership, they can change the leadership themselves, or they can demand a new organisational process that is based on collective decision making. All of these options presuppose an active membership.

\section{Messages for social work education and social work academics}

Besides the PASW and the social work profession, social work education and social work academics have an important role to play in ensuring that the profession is relevant to its social justice values claims. Overall, there is a need to scrutinise the social work education curriculum, scholarly research and teaching, as well as overall engagement. The current social work curriculum is rooted in the past, applying methods and theories relevant to the social democratic phase of capitalism, and thus needs to be re-examined. The curriculum needs to provide tools, such as knowledge related to community organising, to equip future social workers to challenge inequalities.

Social work academics have to make sure that the curriculum of social work education reflects the struggles of both the past and the present in order to provide the inspiration needed to mobilise 
more graduates to engage in collective struggles against injustice. As far as the struggles of the past are concerned, these could be from the history of the development of the welfare state. The welfare state developed as the result of class struggles. The labour movement and other progressive organisations asserted a claim for rights that contradicted the reign of business over people. Social protection and social rights were achieved only when people collectively mobilised into movements to demand a people's agenda. Less than a century ago, people realised that they could only change the balance of forces and meet the needs of the people by collective action. In terms of contemporary struggles, activist initiatives such as the Social Work Action Network (SWAN), founded in the UK and spread to other countries, provide an example of how activist social workers, practitioners, academics, students and social service users can engage in an ideological battle. Teaching about SWAN can be a source of inspiration. In Greece, members of the Greek SWAN have been successful in resisting the participation of social workers in disconnecting the supply of electricity to people unable to pay the xaratsi (an arbitrarily imposed house tax), but also have been actively participating in committees to stop the state from disconnecting electricity. Another optimistic example of struggle comes from the World Social Forum (Ferguson \& Lavalette, 2006). This example is particularly important because it encompasses an organisational model that cuts across national boundaries and reflects a realisation that issues faced at a local level are part of a neoliberal global agenda that needs to be challenged. This connection between social problems and the neoliberal global project needs to be reflected in the curriculum through the incorporation of issues of globalisation and to help explain the need for coalition building globally.

In addition, social work academics must utilise activist research in order to document injustices committed against people. Research is needed to promote the goals of social justice, as is research that can be utilised by grassroots groups. Of course, the pressures put upon social work academics by a 'publish or perish' culture may be an obstacle (McDonald et al., 2003), but there are critical social work journals where social work scholars can publish.

It is clear that changing socioeconomic conditions necessitate new responses from the profession (Reisch \& Jani, 2012). The new responses can be developed by providing a more critical social work curriculum, by critical research and by coalition building across national lines. They can be developed by reclaiming the spirit of social work as envisioned by one of the founding mothers of social work. During the National Conference of Social Work in 1920, Jane Addams (1920/2005, p. 213) said:

I would like to speak ... to my colleagues in the same profession and to state frankly that I thought many times, that unless as social workers we comprehend this situation and take hold of it and cease not until it is rectified, we are not worth our salt. After all, what is the spirit of social work?

She continued by arguing that social workers should address global problems. They should not concentrate on their own countries; they should create international connections (1920/2005). Addams's call to action remains relevant as we face rising inequalities. We need to reclaim the spirit of social work that she described so eloquently. To uphold values of social justice, social workers must actively engage in struggles of resistance. They must question the types of strategies employed at national and international levels. The leadership of PASWs have been reluctant in the past to challenge oppressive conditions that undermined social justice values (loakimidis, 2011; Mazibuko \& Gray, 2004; Yu, 2006, 2008), but it is to be hoped that this is not the case now, and that SKLE is simply immobilised by the previous culture of social partnership. Overall, PASWs stand at the 
crossroad as they face strategic dilemmas. Whether they rise to the challenges raised by the deterioration of socioeconomic conditions or accommodate those socioeconomic conditions remains to be seen.

\section{Notes}

1. 'The purchasing power standard (PPS) is the name given by Eurostat to the artificial currency unit in which the PPPs and real final expenditures for the EU' countries are expressed, namely, euros based on the EU countries (OECD, 2007).

2. This research is part of a larger ongoing research project that addresses the social work profession's response to the Greek PDC and the imposition of the Structural Adjustment Program.

3. The issue referred to here is the exclusion of the social work profession from the policy that states that, for every five people retired, one should be rehired. This policy was in effect at the time of the interview. Currently, the policy states that, for every ten people retired, only one should be rehired.

4. See note [1] above.

5. Scholars have linked clientelistic practices with practices found in countries in the southern Mediterranean area, Latin America and Africa. However, when we make claims of patronage and clientelism, we must not ignore the fact that corporate lobbying strategies employed in Western countries are, in reality, corporate clientelistic practices. They involve mutually beneficial relationships between the political and economic elite. To ignore this can obscure the fact that many activities that occur in the top echelons of society are far worse (Alter-EU, 2010). This can be considered a biased way to frame the political discussion and obscure the actual interfaces between the political and economic elite.

6. The inclusion of the adjective 'western' was intentional, primarily to denote that there might be other non-western ones that implement activist strategies, for example, from countries from Latin America, but because of a lack of English literature, this is not possible to ascertain in detail.

\section{References}

- 1. Addams, J. (1920/2005). The spirit of social service. In M. Fisher \& J. Whipps (Eds.) Jane Addams essays and speeches (pp. 213-217). London: Continuum International Publishing Group.

- 2. Alter-EU. (2010). Bursting the Brussels bubble: The battle to expose corporate lobbying at the heart of the EU. Brussels: Author. Retrieved from http://www.altereu.org/sites/default/files/documents/bursting-the-brussels-bubble.pdf

- 3. Arad, N. (1972). The role of professional association of social workers in influencing social policy. International Social Work, 15, 18-23. doi:10.1177/002087287201500104 [CrossRef]

- 4. Braun, V., \& Clarke, V. (2006). Using thematic analysis in psychology. Qualitative Research in Psychology, 3(2), 77-101. doi:10.1191/1478088706qp063oa [Taylor \& Francis Online]

- 5. Donald, H. (2011). UNICEF social protection work - An overview. Retrieved from http://prezi.com/tInni_srqviq/unicef-social-protection-work-an-overview

- 6. European Commission. (2012). EU employment and social situation. Quarterly review-June 2012. Retrieved from ec.europa.eu/social/BlobServlet?docld=7830\&langld=en 
- 7. Eurostat Press Office. (2012). Newsrelease 171/2012. Retrieved from http://epp.eurostat.ec.europa.eu/cache/ITY_PUBLIC/3-03122012-AP/EN/3-03122012-APEN.PDF

- 8. Ferguson, I., \& Lavalette, M. (2006). Globalization and global justice: Towards a social work of resistance. International Social Work, 49, 309-318. doi:10.1177/0020872806063401 [CrossRef], [Web of Science ${ }^{\circledR}$ ]

- 9. Ferguson, I., \& Woodward, R. (2009). Radical social work in practice. Bristol: Policy Press.

- 10. Fondeville, N., \& Ward, T. (2011). Homelessness during the crisis. European Commission, Directorate - General for Employment, Social Affairs and Inclusion. Retrieved from http://www.socialsituation.eu/research-notes/SSO\%20RN8\%20Homelessness_Final.pdf

- 11. Gillingham, P. (2007). The Australian Association of Social Workers and social policy debates: A strategy for the future?Australian Social Work, 60(2), 166-180. doi:10.1080/03124070701323808 [Taylor \& Francis Online]

- 12. Greek National Medical Conference. (2012, May 14-16). Press Release of the Greek National Medical Conference.

- 13. Harvey, D. (2005). A brief history of neoliberalism. Oxford: Oxford.

- 14. Hyman, R. (2010). Social dialogue and industrial relations during the economic crisis: Innovative practices or business as usual? DIALOGUE Working Paper, 11. Geneza, Switzerland: International Labour Organization.

- 15. IASSW, \& ICSW \& IFSW. (2012, July 8-12). Joint World Conference on Social Work and Social Development, Action and Impact, Sweden. Retrieved from http://www.swsdstockholm-2012.org/Pdf/PAAG_full_120705.pdf

- 16. IMF. (2012). World economic outlook: Coping with high debt and sluggish growth. Retrieved from http://www.imf.org/external/pubs/ft/weo/2012/02/pdf/text.pdf

- 17. International Association of Schools of Social Work (IASSW), the International Council on Social Welfare (ICSW), and the International Federation of Social Workers (IFSW). (2010, June 10-14). Rising to the global challenge: IASSW, ICSW and IFSW join hands to build an agenda for the next decade. 2010 Joint World Conference on Social Work and Social Development, The Agenda, Honk Kong. Retrieved from http://www.swsd2010.org/en/welcome.html

- 18. loakimidis, V. (2011). Expanding imperialism, exporting expertise: International social work and the Greek project, 1946-1974. International Social Work, 54, 505-519. doi:10.1177/0020872810385832 [CrossRef], [Web of Science ${ }^{\circledR}$ ]

- 19. Jepsen, M., \& Serrano, P. A. (2005). The European social model: An exercise in deconstruction. Journal of European Social Policy, 15, 231-245. doi:10.1177/0958928705054087 [CrossRef], [Web of Science ${ }^{\circledR}$ ]

- 20. Karger, H. J., \& Hernandez, M. T. (2004). The decline of the public intellectual in social work. Journal of Sociology and Social Welfare, 31(3), 51-68.

- 21. Kentikelenis, A., Karanikolos, M., Papanicolas, I., Basu, S., McKee, M., \& Stuckler, D. (2011). Health effects of financial crisis: Omens of a Greek tragedy. The Lancet, 378, 14571458. doi:10.1016/S0140-6736(11)61556-0 [CrossRef], [PubMed], [Web of Science ${ }^{\circledR}$ ]

- 22. Kincheloe, J. L., \& McLaren, P. (2000). Rethinking critical theory and qualitative research. In N. K. Denzin \& Y. S. Lincoln (Eds.), Handbook of qualitative research (pp. 279-314). Thousand Oaks, CA: Sage.

- 23. Lavalette, M., \& Ferguson, I. (Eds.). (2007). International social work and the radical tradition. Birmingham: Venture Press.

- 24. Marston, G., \& McDonald, C. (2012). Getting beyond 'heroic agency' in conceptualizing social workers as policy actors in the twenty-first century. British Journal of Social Work, 42, 1022-1038. doi:10.1093/bjsw/bcs062 [CrossRef], [Web of Science ${ }^{\circledR}$ ] 
- 25. Mazibuko, F., \& Gray, M. (2004). Social work professional associations in South Africa. International Social Work, 47(1), 129-142. doi:10.1177/0020872804039391 [CrossRef], [Web of Science ${ }^{\circledR}$ ]

- 26. McDonald C., Harris, J., \& Wintersteen, R. (2003). Contingent on content? Social work and the state in Australia, Britain, and the USA. British Journal of Social Work, 33, 191-208. doi:10.1093/bjsw/33.2.191 [CrossRef], [Web of Science ${ }^{\circledR}$ ], [CSA]

- 27. Mendes, P. (2003). Social workers and social action: A case study of the Australian Association of Social Workers' Victorian Branch. Australian Social Work, 56(1), 16-27. doi:10.1046/j.0312-407X.2003.00053.x [Taylor \& Francis Online], [CSA]

- 28. Milanovic, B. (2010). The haves and the have-nots: A brief and idiosyncratic history of global inequality. New York, NY: Basic Books.

- 29. Nancy, J.-L. (1992). La comparution/The compearance: From the existence of "Communism" to the Community of "Existence". Political Theory, 20, 371-398. doi:10.1177/0090591792020003001 [CrossRef], [Web of Science ${ }^{\circledR}$ ], [CSA]

- 30. OECD. (2007). Glossary of terms - purchasing power standard. Retrieved from http://stats.oecd.org/glossary/detail.asp?ID $=7184$.

- 31. Payne, M. (2002). The role and achievements of a professional association in the late twentieth century: The British Association of Social Workers 1970-2000. British Journal of Social Work, 32, 969-995. doi:10.1093/bjsw/32.8.969 [CrossRef], [Web of Science ${ }^{\circledR}$ ], [CSA]

- 32. Pentaraki, M. (2013a). 'If we do not cut social spending, we will end up like Greece': Challenging consent to austerity through social work action. Critical Social Policy, 33(4), 700711.doi:10.1177/0261018313489941

- 33. Pentaraki, M. (2013b, March 25-27). The New European Economic Governance (NEEG): EU's austerity project, its effects on the welfare state and struggles of resistance. A discussion paper presented at the international conference on Alternative Futures and Popular Protest hosted by Manchester Metropolitan University, UK.

- 34. Petmesidou, M. (2006). Social care services: "Catching Up" Amidst high fragmentation and poor initiatives for change., In M. Petmesidou \& E. Mossialos (Eds.), Social policy developments in Greece (pp. 319-357). Aldershot: Ashgate.

- 35. Reisch, M., \& Andrews, J. (2002). The road not taken: A history of radical social work in the United States. New York, NY: Brunnel-Routledge.

- 36. Reisch, M., \& Jani, J. S. (2012). The new politics of social work practice: Understanding context to promote change. British Journal of Social Work, 42, 1132-1150. doi:10.1093/bjsw/bcs072 [CrossRef], [Web of Science ${ }^{\circledR}$ ]

- 37. Roniger, L. (2004). Political clientelism, democracy, and market economy. Comparative Politics, 36, 353-375. doi:10.2307/4150135 [CrossRef], [Web of Science ${ }^{\circledR}$ ]

- 38. Specht, H., \& Courtney, M. (1994). Unfaithful angels: How social work has abandoned its mission. New York, NY: The Free Press.

- 39. Swyngedouw, E. (2011). Interrogating post-democratization: Reclaiming egalitarian political spaces. Political Geography, 30, 370-380. doi:10.1016/j.polgeo.2011.08.001 [CrossRef], [Web of Science ${ }^{\circledR}$ ]

- 40. United Nations (UN). (2011, November). Human development report 2011. Sustainability and equity: $A$ better future for all. Retrieved from http://hdr.undp.org/en/reports/global/hdr2011/download/.

- 41. Wilkinson, R., \& Picket, K. (2009). The spirit level: Why equality is better for everyone. London: Penguin.

- 42. Yu, N. G. (2006). Interrogating social work: Philippine social work and human rights under martial law. International Journal of Social Welfare, 15, 257-263. doi:10.1111/j.14682397.2006.00401.x [CrossRef], [Web of Science ${ }^{\circledR}$ ]

- 43. Yu, N. G. (2008). Class identity, class interests: The Philippine Professional Association of Social Workers' record under martial law. Asia Pacific Journal of Social Work and 
Development, 18(1), 3-13. doi:10.1080/21650993.2008.9756028 [Taylor \& Francis Online], [Web of Science ${ }^{\circledR}$ ] 